\title{
Variasi leksikal dialek Melayu di negeri Kedah: Kajian geolinguistik
}

\author{
Fazal Mohamed Mohamed Sultan ${ }^{1}$, Amir Imran Jamil ${ }^{2}$ \\ ${ }^{1}$ Pusat Bahasa dan Linguistik, Fakulti Sains Sosial dan Kemanusiaan Universiti Kebangsaan Malaysia \\ ${ }^{2}$ Sime Darby, Kuala Lumpur
}

Correspondence: Fazal Mohamed Mohamed Sultan (email: fazal@ukm.edu.my)

Received: 04 August 2019; Accepted: 31 October 2019; Published: 25 November 2019

\begin{abstract}
Abstrak
Data linguistik sesebuah dialek boleh digabungkan dengan teknologi terkini iaitu teknologi Geographical Information System (GIS) untuk menghasilkan sebuah peta dialek. Hasil gabungan di antara data dialek dengan teknologi ini membolehkan satu gambaran sempadan dialek dilakarkan dengan lebih tepat. Justeru, teknologi Geographical Information System $(G I S)$ ini diguna pakai dalam artikel ini untuk menghasilkan peta variasi dialek Melayu di Kedah. Kajian geolinguistik ini bermula dengan pengumpulan data leksikal yang dibuat menerusi kajian lapangan di 135 buah kampung di 11 mukim di negeri Kedah berdasarkan kaedah soal selidik dan rakaman. Seramai 892 responden yang terdiri daripada generasi tua dan muda disoal selidik. Kajian ini juga mengaplikasikan penggunaan teknologi yang berbantukan GIS iaitu ArcGIS dalam menjana peta penyebaran leksikal bagi dialek Melayu di negeri Kedah. Dapatan kajian menunjukkan bahawa taburan bagi leksikal 'punggung' dan 'kerbau' sebenarnya mempunyai polanya yang tersendiri. Hal ini dapat dikukuhkan lagi dengan pembuktian GIS iaitu maklumat-maklumat geografi atau bentuk muka bumi seperti sungai, paya, gunung, bukit dan hutan boleh menjadi faktor penentu kepada penyebaran dialek Melayu di Kedah. Keadaan ini menunjukkan bahawa penyebaran leksikal bagi sesuatu dialek akan mudah tersebar sekiranya terdapat ruang (spatial) yang memudahkannya tersebar ke kawasan yang berhampiran. Hasilnya, satu pemetaan isoglos baru berjaya dipetakan bagi memperlihatkan variasi leksikal dialek Melayu di Kedah dengan tepat.
\end{abstract}

Kata kunci: dialek, geo-linguistik, GIS, isoglos, Kedah, variasi leksikal

\section{The variation of Malay lexical dialect In Kedah: A geolinguistics study}

\begin{abstract}
The linguistic data of a dialect can be combined with the latest Geographical Information System (GIS) technology to produce a dialect map. The result of a combination between dialect data and technology enables a more accurate map of dialect boundaries. Hence, Geographical Information System (GIS) technology is used in this article to produce a map of Malay dialect variations in Kedah. This geolinguistics study starts off with the gathering of
\end{abstract}


lexical data through field research that has been conducted in 135 villages in Kedah based on questionnaire and recording method. There are 892 respondents that are from the old and young generation. This study applies the use of technology with the assistance of GIS, which is ArcGIS, to generate the map of spreading lexical for Malay dialects in Kedah. The findings show that the

lexical punggung" and "kerbau" have their own patterns. This has been strengthened and proven by GIS that showed this geographical information or the land form such as rivers, swamp, hills and forests can be the factors of spreading of Malay dialects in Kedah. This shows that the dialect can be spread easily if there is space (spatial) to make it easy to be spread to its surroundings. As a result, new isoglos mapping has been produced to show the variety of Malay dialect lexical in Kedah precisely. As a result, a new isoglos mapping was successfully mapped to show the lexical variants of the Malay dialect in Kedah accurately.

Keywords: dialect, geo-linguistics, GIS, isoglos, Kedah, lexical variation

\section{Pengenalan}

Kajian-kajian dialek sememangnya merupakan suatu kajian bahasa yang menarik untuk diterokai. Hal ini terbukti berdasarkan kajian yang telah dilakukan oleh pengkaji lepas yang mendeskripsikan sesebuah kajian dialek dalam pelbagai kaedah (Fazal Mohamed \& Noriati, 2017; Sakinah Nik \& Fazal Mohamed, 2016). Istilah dialek berasal daripada perkataan Yunani dialektos iaitu 'manner of speech'. Dialek adalah variasi bahasa yang dituturkan oleh sekelompok penutur tertentu dan di kawasan tertentu yang melampaui sempadan politik. Walaupun wujudnya perbezaan dialek di kawasan-kawasan tersebut, tetapi kadar kesalingfahaman terhadap semua dialek adalah tinggi. Malah penyebaran semua dialek masih menunjukkan kesinambungan yang ketara walaupun sebutannya berbeza (Meillet, 1967).

Dialek sebagai satu sub-bahasa yang mewakili bahasa tuturan sesebuah penduduk di satu-satu kawasan (Asmah, 1985). Collins (1986) mentakrifkan dialek sebagai satu ragam bahasa yang dibezakan secara tegas daripada ragam-ragam lain berdasarkan ciri-ciri penyebutan, kosa kata dan tatabahasa. Tambahnya lagi, ragam bahasa ini terdapat dalam daerah geografi tertentu dan dalam suasana sosial tertentu. Keterwakilan dialek yang dibentuk bagi sesebuah kawasan adalah berbeza dari suatu komuniti dengan komuniti yang lain. Buktinya, di Malaysia terdapat pelbagai dialek mengikut daerah seperti yang dikemukakan oleh Asmah (1985). Hal ini turut sama dihujahkan oleh Mario \& Gaynor (1960) dan Abdul Hamid Mahmood (1993) yang menyatakan bahawa dialek merupakan bentuk khusus sesuatu bahasa yang dituturkan oleh sekumpulan penutur di daerah tertentu atau di kawasan geografi tertentu. Hal ini jelas menunjukkan bahawa dialek dan kawasan geografi merupakan perkara yang saling berkaitan antara satu sama lain.

Disebabkan penyebaran dialek-dialek Melayu ini meliputi satu kawasan yang sangat luas, maka keadaan ini jelas menunjukkan bahawa wujudnya satu keperluan untuk melaksanakan penelitian dan kajian terhadap dialek Melayu. Memandangkan perubahan teknologi dapat membantu menambah baik cara pemetaan dialek dilakukan, maka kajian ini akan memfokuskan kepada penggunaan perisian Sistem Maklumat Geografi (GIS). Sistem ini dilihat dapat membantu memaparkan penyebaran leksikal dalam dialek Kedah dengan lebih tepat dan sekali gus membuktikan bahawa kerencaman yang dinyatakan oleh pengkaji lepas itu terbukti secara saintifik. Hal ini kerana, GIS telah diguna pakai dalam kajian dialek dan pemetaan isoglos di bahagian lain di dunia. GIS merupakan perisian geografi yang boleh memaparkan maklumat bentuk muka bumi sesuatu tempat tetapi pada masa yang sama datadata linguistik dapat dimasukkan melalui data atribut dan terus dihubungkan dengan 
maklumat geografi. Kajian ini cuba memurnikan peta dialek Kedah yang pernah dihasilkan oleh pengkaji terdahulu. Hasil kajian akan dapat memberikan gambaran taburan penutur dialek Melayu Kedah yang terdapat di kawasan kajian. Dengan itu juga pemetaan dialek yang selama ini hanya berdasarkan lakaran akan digantikan dengan penggunaan teknologi yang lebih tepat.

\section{Kajian lepas}

Kajian dan penelitian mengenai dialek geografi sememangnya telah banyak dilakukan oleh pengkaji-pengkaji terdahulu. Penulis membahagikan perbincangan kajian-kajian lepas kepada tiga (3) pecahan utama iaitu dialek umum, dialek geografi dan dialek geografi dan teknologi. Bagi kajian dialek umum, penulis mendapati bahawa kajian yang dilakukan oleh Asmah (1985) yang meneliti keseluruhan dialek di Malaysia telah memberi dapatan yang jelas berkenaan variasi dialek kawasan yang wujud di setiap negeri. Penjelasan variasi tersebut dijelaskan berdasarkan dialek dan sub dialek yang terdapat di kawasan tersebut. Penelitian kajian dialek umum juga turut dikemukakan oleh Collins (1996) dan Ismail (1997). Ketiga-tiga kajian ini tertumpu kepada pengolahan data yang melibatkan variasi perbezaan dan persamaan bunyi dalam dialek dan sub dialek berkenaan. Dapatan yang berbeza juga dilihat daripada ketiga-tiga kajian ini memandangkan penjelasannya yang terhad kepada keterwakilan satu-satu dialek atau sub dialek daerah yang dikaji tanpa meneliti setiap mukim dan kampung-kampung dalam kawasan tersebut. Hal ini jelas menunjukkan ketiga-tiga kajian ini merupakan kajian dialek umum. Hal ini kerana, penjelasan yang dilakukan hanya berdasarkan kepada keterwakilan dalam dialek yang diteliti bagi sesuatu negeri tanpa meneliti aspek yang lebih mendalam seperti titik kampung dan kehadiran ruang dan bentuk muka bumi yang terdapat di kawasan tersebut. Begitu juga dengan pemetaan dialek. Hanya Asmah (1985) yang dapat memaparkan peta isoglos di Malaysia. Namun pemetaan yang dilakukan hanyalah lorekan secara manual semata-mata. Ini boleh meragukan pembaca tentang ketepatan representasi dialek atau sub dialek di kawasan tersebut.

Seterusnya, kelompok dialek geografi. Antaranya kajian yang dihasilkan oleh Collins (1983), Ajid (1984), Rohani (1986), Collins (1987) dan Mohd Tarmizi et al. (2012). Dalam kelima kajian lepas ini, kajian yang dilakukan oleh Rohani (1986) membincangkan tentang dialek geografi di Kuala Kangsar, Perak dan merupakan antara salah satu kajian yang lengkap tentang dialek geografi. Hal ini kerana, dalam disiplin dialek geografi, antara perkara yang paling utama yang perlu dikemukakan oleh pengkaji disiplin ini ialah penjanaan dan pemaparan peta bagi kawasan yang dikaji. Melalui penghasilan sesebuah peta isoglos tersebut, pengkaji dapat memperlihat perkaitan dengan ciri-ciri seperti sempadan negeri atau daerah, bentuk muka bumi, ruang geografi dan sebagainya. Justeru, kajian yang dihasilkan oleh Rohani dilihat merupakan antara salah satu kajian dialek geografi yang menunjukkan hasil peta yang baik. Garisan sempadan kawasan, sungai, dan jalan raya kelihatan lebih teliti. Namun, masih lagi wujud simbol yang bersifat lakaran pada peta yang dihasilkan. Rohani menggunakan kaedah lorekan berwarna bagi menunjukkan penyebaran satu-satu ciri dialek di Kuala Kangsar. Pemaparan peta variasi leksikal dan isoglos yang dihasilkan secara manual juga menimbulkan tanda tanya ketetapan keadaan sebenar kawasan kajian. Hal ini mungkin memberi kesan kepada ketepatan dan kejelasan kedudukan kawasan kajian. Selain itu, perkara yang sama turut dilihat berlaku kepada kajian-kajian lain seperti Collins (1983), Ajid (1984) dan Mohd Tarmizi et al. (2012), di mana pengkaji-pengkaji ini juga turut menghasilkan peta yang bersifat lorekan semata-mata. Seperti juga dengan kajian dialek umum, pengkaji dialek geografi ini juga dilihat kurang berjaya dalam mengemukakan paparan peta yang lebih jelas dan tepat. Paparan peta yang dihasilkan dengan cara ini dianggap lebih bersifat impresionistik oleh Teeraroanarat dan Tigsabadh (2011). Walau 
bagaimanapun, penjelasan dan penghuraian berkenaan dengan fonologi dan leksikal yang dikemukakan oleh pengkaji ini diterangkan dan dijelaskan dengan baik. Kekurangannya dilihat terhadap kekangan alat dan teknologi menyebabkan keterbatasan kepada pengkajipengkaji terdahulu dalam menghasilkan peta isoglos dalam kajian mereka.

Ketiga, berkenaan dengan kajian multidisiplin iaitu gabungan dialek dan teknologi. Gabungan dengan aplikasi GIS ini dapat membantu pengkaji lepas dalam kelompok ini membawa dimensi baharu kepada kajian dialek dengan menerapkan bantuan teknologi semasa iaitu GIS. Aplikasi teknologi GIS ini dapat membantu penulis dan meneliti fenomena geografi yang mempengaruhi pembentukan mahupun penyebaran sesuatu bahasa mahupun dialek. Membentuk satu-satu peta sebenarnya memerlukan kemahiran dalam bidang geografi. Maka, pengkaji bahasa perlu memanfaatkan ilmu geografi dalam menambah baik aspek pemetaan. Dunia teknologi semakin berkembang dan seiring dengan itu, kaedah pemetaan berevolusi. Bermula dengan hanya bersifat lakaran, kini peta boleh dihasilkan dengan bantuan teknologi (GIS). GIS ini sangat popular dalam bidang geografi dan kini turut digunakan dalam kajian kebahasaan. Onishi (2010) misalnya, berjaya menunjukkan bahawa altitud dan kepadatan penduduk merupakan faktor penyebaran satu-satu dialek. Jika dilihat pada kawasan kajiannya, ianya meliputi keseluruhan negara Jepun. Bermakna, teknologi GIS ini mampu memproses data yang besar. Selain itu, Teerarojanarat dan Tingsabadh (2011) turut memanfaatkan GIS dalam kajian mereka di Thailand dan berjaya membentuk isoglos dialek dengan baik. Di Malaysia, antara kajian yang menggunakan GIS ialah Nor Hashimah (2015), Nor Hashimah et al. (2016) dan Maizatul Hafizah (2016). Dalam kajian tersebut, mereka menekankan aspek bentuk muka bumi dan ruang geografi yang turut dimuatkan dalam peta isoglos kajian. Maklumat dalam peta disediakan oleh Jabatan Pemetaan dan Ukur Malaysia (JUPEM) yang diakui tepat. Oleh itu, isu ketepatan penyebaran dialek sukar untuk dipersoalkan. Malah, mereka turut membincangkan aspek sejarah dan migrasi yang dikaitkan dengan faktor penyebaran sebuah dialek tersebut.

\section{Metodologi kajian}

Kajian ini memberi tumpuan kepada pola peralihan dialek bagi leksikal punggung dan kerbau dengan menggunakan pendekatan yang berbantukan GIS. Kawasan kajian yang dipilih untuk kajian dialek ini adalah negeri Kedah Darul Aman. Pemilihan negeri Kedah adalah disebabkan wujudnya pelbagai kerencaman di dalam sub dialeknya. Malah, kedudukan negeri Kedah yang bersempadan dengan banyak negeri di sekelilingnya telah menjadikan dialek Melayu ini berbeza dengan dialek lain. Kesemua daerah yang terdapat di negeri Kedah dikaji, kecuali Langkawi, dan dianalisis bagi melihat variasi leksikal dialek Melayu di negeri tersebut.

Kajian ini melibatkan informan. Oleh itu, perancangan yang betul untuk mendapatkan sumber yang boleh dipercayai adalah penting. Kajian ini mempunyai responden utama yang dipilih dari sub-daerah dan kampung-kampung tertentu. Berikutan itu, satu kajian awal telah dilakukan. Pengkaji mendekati ketua daerah yang dikenali sebagai Penghulu untuk menentukan penutur asli Melayu. Penghulu akan menghubungi ketua kampung untuk mengenal pasti penutur dialek Kedah.

Seterusnya, penulis hanya memfokuskan kepada dua (2) leksikal sahaja iaitu leksikal 'punggung' dan 'kerbau'. Pemilihan kedua-dua leksikal ini dibuat berdasarkan beberapa faktor. Antaranya ialah kesemua leksikal ini mempunyai variasi sebutan yang banyak iaitu melebihi lima. Kebanyakan leksikal lain yang turut diuji dan dikaji hanya mendapat lima variasi dan ke bawah. Variasi yang banyak membuktikan bahawa leksikal ini kerap dan meluas penggunaannya (Fazal Mohamed Mohamed Sultan \& Noriati Muhamad, 2017). 
Malah, menerusi variasi yang pelbagai inilah unsur atau pengaruh dialek tertentu dapat dikenal pasti. Pengaruh dialek inilah yang cuba dicungkilkan dalam kajian ini. Selain itu, setiap leksikal ini mewakili kategori kata utama iaitu kata nama dalam bahasa Melayu.

Setelah selesai pengumpulan data, penyelidik akan memindahkan data ke dalam program Microsoft Office Excel. Semua perbezaan yang dikenal pasti disenaraikan dalam Microsoft Office Excel. Setelah melengkapkan data, data sekali lagi dipindahkan, dan kali ini ke dalam perisian ArcGIS. Sistem Maklumat Geografi (GIS) adalah satu perisian yang mampu untuk menggabungkan data linguistik bersama-sama dengan analisis spatial. Teknik-teknik berasaskan penggunaan alat GIS adalah untuk mengintegrasikan pendekatan konvensional bahasa dan membantu untuk menghasilkan isoglos yang lebih sistematik bagi sub-dialek yang dituturkan di negeri Kedah.

\section{Analisis dan perbincangan}

Bahagian analisis dan perbincangan tertumpu kepada satu analisis utama dalam kajian ini sahaja, iaitu analisis terhadap penyebaran variasi leksikal dialek Melayu di negeri Kedah yang disebabkan oleh faktor geolinguistik faktor ruang geografi atau geospatial. Tambahan lagi, dalam bahagian ini penulis juga menumpukan penganalisisan dari aspek muka bumi dan ruang dan seterusnya menghasilkan pemetaan isoglos bagi kedua-dua leksikal yang dikaji dalam kalangan penutur di negeri Kedah.

\section{Faktor geolinguistik}

Berdasarkan kepada analisis fonologi yang dilakukan, penulis mendapati bahawa setiap perilaku fonologi yang terjadi berkait rapat dengan faktor ruang geografi. Pembentukan dialek yang dipengaruhi oleh faktor ruang geografi membawa kepada pembentukan variasi dialek yang pelbagai. Kepelbagaian kepada variasi dialek di negeri Kedah telah membentuk pemetaan yang khusus kepada lingkungan persempadan kawasan dialek. Pemetaan yang dimaksudkan ialah pemetaan isoglos. Malah, kepelbagaian dialek di negeri Kedah juga dilihat telah membentuk pelbagai varian dari segi leksikal mahupun fonologinya.

\section{Pemetaan varian leksikal 'punggung'}

Berdasarkan data diperolehi, dapat dikenal pasti bahawa terdapat enam (6) varian yang merujuk kepada leksikal 'punggung' dalam kalangan penutur di negeri Kedah. Antara varian-

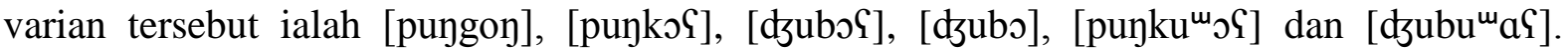
Kehadiran varian-varian ini dilihat adalah disebabkan oleh faktor ruang geografi di kawasan tersebut sama ada membuka atau menutup ruang kepada penyebaran ke kawasan sekitarnya. Peta isoglos bagi leksikal 'punggung' (rujuk Rajah 1) memaparkan kawasan penyebaran varian-varian bagi leksikal 'punggung' beserta dengan taburan bentuk muka bumi yang terdapat dalam negeri Kedah.

\section{a. Varian bunyi [pungon]}

Berpandukan kepada peta isoglos dalam rajah 1, di bahagian selatan negeri Kedah, dapat diperhatikan bahawa kesemua kampung di daerah Bandar Baharu menggunakan varian [pungon]. Varian [pungoy] merupakan penyebutan standard bahasa Melayu yang mengekalkan konsonan nasal [y] di akhir kata (Asmah, 2008). Malah, kebanyakan varian ini ditemui di kesemua kampung dalam daerah Bandar Baharu dan sebahagian kecil di kampung 
di daerah Kulim. Penyebaran varian [puygon] yang ditandai dengan warna kuning langsat (yellow mustard) di dalam peta isoglos tersebut memperlihatkan kawasan penyebaran varian ini di daerah yang terlibat.

Varian ini dapat dilihat penyebarannya di seluruh kampung di daerah Bandar Baharu, iaitu Kampung Asam Kumbang, Kampung Permatang Simpur, Kampung Sungai Tepus, Kampung Padang Sungai Kecil Hilir, Kampung Hulu, Kampung Paya Semambu, Kampung Bukit Tok Gula, Kampung Tok Din dan hanya satu kampung sahaja ditemui di daerah Kulim, iaitu Kampung Keda Bagan Sena. Tambahan pula, kebanyakan petempatan yang dibina di dalam daerah ini adalah didiami oleh penduduk yang berasal daripada luar negeri Kedah yang datang melalui Skim Tanah Rancangan. Oleh sebab itu, pertuturan masyarakat di Bandar Baharu ini lebih kepada bentuk standard atau menggunakan dialek asli Selangor sesama mereka.

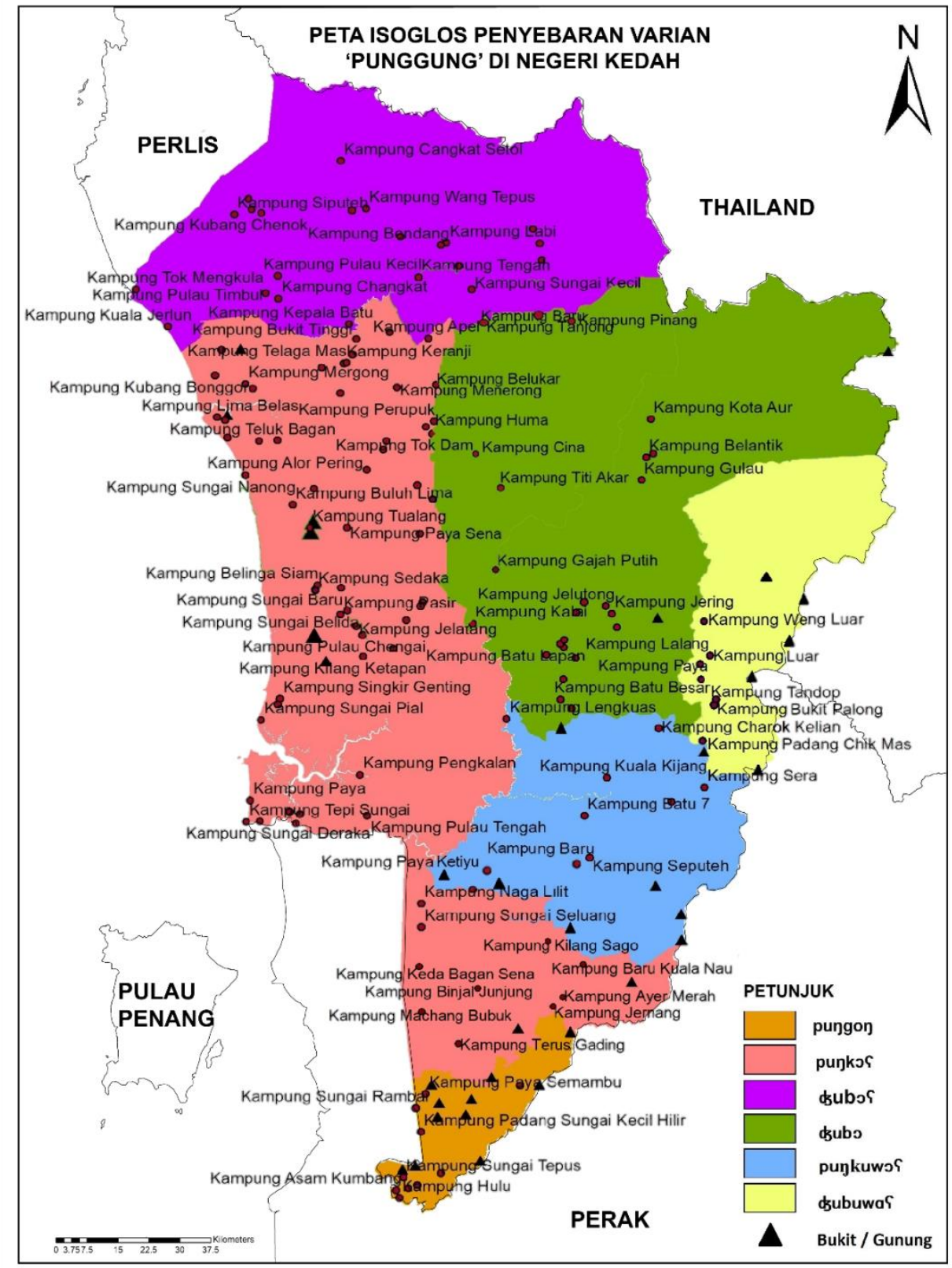

Rajah 1. Varian leksikal 'Punggung' 
Namun begitu, penyebaran varian [pungon] didapati tidak pula tersebar ke bahagian Hilir Kedah atau lebih dikenali sebagai Lembah Kedah (Asmah, 2008) seperti Kuala Muda, Yan, Pendang dan Kota Setar. Hal ini kerana, terdapat gunung dan bukit yang menghalang kemasukan pengaruh varian [pungon] di antara Bandar Baharu dan Hilir Kedah atau Lembah Kedah. Malah, subkawasan Lembah Kedah ini mempunyai beberapa pusat pentadbiran dan kebudayaan yang utama bagi seluruh negeri Kedah iaitu, Alor Setar yang merupakan ibu negeri Kedah, Sungai Petani di selatan dan Jitra di utara. Hal ini menyebabkan pengaruh dialek asli Melayu Kedah dilihat lebih dominan di kawasan Lembah Kedah ini. Tambahan pula, terdapat gunung dan bukit yang menghalang kemasukan pengaruh varian [pungoy] di antara daerah Bandar Baharu dan bahagian Lembah Kedah yang turut menjadi penghalang kepada kemasukan varian [pungon] di kawasan tersebut. Antara bukit tersebut ialah Bukit Belakang Parang, Bukit Relau, Bukit Sama Gajah, Bukit Jambi, Bukit Merah, Gunung Jenehing dan Bukit Lawan.

\section{b. Varian bunyi [punkə९]}

Varian bunyi [punko؟] merupakan sebutan daripada subdialek Kedah Persisiran atau lebih dikenali sebagai dialek Kedah standard. Menurut Asmah (2008), subdialek Kedah Persisiran ini dianggap sebagai dialek Kedah yang standard, yakni subdialek yang digunakan dalam pertuturan-pertuturan tak bersahaja (formal) di Kedah, dan subdialek ini jugalah yang menjadi asas bahasa diraja Kedah. Berpandukan kepada peta isoglos (Rajah 1), didapati penyebaran [punko؟] adalah dominan di daerah Kulim, Yan dan Kuala Muda.

Ini kerana bentuk muka bumi daerah Kulim, Yan dan Kuala Muda yang bertanah rendah dan rata serta berdekatan dengan Kota Setar yang turut menerima pengaruh dialek asli Melayu Kedah memudahkan penyebaran varian ini berbanding dengan varian dialek Petani Baling, dialek Petani Sik, dialek Siam dan bahasa standard atau dialek Selangor. Tambahan lagi, dengan kehadiran Gunung Bongsu, Gunung Bintang dan Gunung Ina di antara Kulim dan Bandar Baharu, gunung-gunung ini dilihat telah menutup ruang kepada penyebaran varian [pungon] di ketiga-tiga kawasan ini dan begitu juga dengan varian [punkə९] yang tidak dapat keluar atau tersebar ke bahagian Bandar Baharu.

Berdasarkan kepada peta isoglos tersebut, dapat dikenal pasti daerah Kota Setar juga dilihat menggunakan varian [puykoS] secara dominan di kesemua kampung seperti kampungkampung di daerah Yan, Kuala Muda dan Kulim. Ini mungkin disebabkan oleh Kota Setar sendiri yang merupakan merupakan pusat pentadbiran serta bandar diraja Kedah iaitu Bandar Anak Bukit menyebabkan varian ini mudah tersebar ke Kota Setar.

\section{c. Varian bunyi [dzubos]}

Varian bunyi [dzuboS] ini juga dianggap sebagai sebutan daripada subdialek Kedah Persisiran atau lebih dikenali sebagai dialek Kedah standard. Varian ini didapati begitu banyak penggunaannya di daerah Kubang Pasu dan menyebar sehingga kepada sebahagian kampung di daerah Padang Terap. Daerah Kubang Pasu dan Padang Terap merupakan daerah yang mempunyai bentuk muka bumi dengan tanah pamah rata dan sedikit berbukit. Daerah ini juga berdekatan dengan Kota Setar. Keadaan ini telah membuka ruang kepada kemasukan pengaruh dialek Melayu Kedah Standard ke kampung-kampung di daerah ini. Oleh sebab itu, didapati kebanyakan penduduk di kampung dalam daerah ini menggunakan varian [ḑubos] bagi merujuk kepada leksikal 'punggung'. 


\section{d. Varian bunyi [dzubo]}

Bagi penggunaan varian [dzubs] pula, didapati penyebaran varian ini hanya ditemui di kebanyakkan kampung di daerah Sik dan sebahagian kampung di Padang Terap dan Pendang. Varian ini merupakan varian yang memiliki identitinya yang tersendiri yang merupakan penyebutan dialek Petani Sik atau juga disebut sebagai Pelat Patani.

Dapat dikenal pasti bahawa kebanyakan varian ini digunakan secara dominan dalam kalangan penutur di daerah Sik dan sebahagian kampung di Padang Terap memandangkan kedudukan geografinya yang bersempadan dengan Thailand. Malahan, di daerah Sik ini dipenuhi oleh kebun buah-buahan dan getah yang telah menarik minat masyarakat Patani untuk berpindah dan membina petempatan di Sik bagi kelangsungan hidup. Oleh sebab itu, kebanyakan kampung dalam daerah ini menuturkan dialek Melayu Patani dalam kehidupan seharian mereka. Keadaan ini telah menjadikan kawasan tersebut sebagai kawasan peralihan antara dialek, iaitu antara dialek Kedah dan dialek Petani seperti yang dikemukakan oleh pengkaji dialek seperti Raja Mukhtaruddin (1986), Asmah (1985) dan Rohani (2003). Penggunaan varian ini dilihat dominan penggunaannya di kebanyakkan di kampung di daerah Sik.

Penyebaran varian [dzubo] bukan sahaja ditemui di daerah Sik sahaja. Malahan, varian ini turut ditemui di daerah Padang Terap dan menyebar sehingga ke sebahagian kecil di daerah Pendang. Kedudukan daerah Padang Terap dan Pendang yang bersempadan atau bersebelahan dengan daerah Sik turut dilihat mempengaruhi kepada penyebaran varian [dzubo] ini. Kemasukan pengaruh dialek Patani Sik atau juga disebut sebagai Pelat Petani ke sebahagian kecil kampung di selatan daerah Padang Terap dan Pendang kerana adanya ruang yang terbuka di antara kedua-dua daerah ini. Buktinya dapat diperhatikan dalam peta isoglos pada rajah 1, geografi atau bentuk muka bumi bagi daerah di antara Sik dengan Pendang dan Padang Terap yang kurang berbukit dan bergunung telah memudahkan pengaruh varian dialek Patani Sik menyebar ke kedua-dua daerah ini.

Tambahan lagi, di antara daerah Sik dan Padang Terap, selain kedudukan kedua-dua daerah ini yang bersempadan antara satu sama lain dan bentuk muka buminya yang kurang berbukit dan bergunung, dua daerah ini juga disaliri Sungai Beris dan ini memudahkan perhubungan berlaku antara kawasan ini. Dengan wujudnya Sungai Beris antara daerah Sik dan Padang Terap ini, ia pastinya wujud aktiviti nelayan yang melibatkan penduduk bagi kedua-dua daerah ini. Sungai Beris ini juga dilihat sebagai jalan penghubung di antara dua kawasan tersebut dan ini secara tidak langsung telah membuka ruang kepada penyebaran dialek Patani Sik ke dalam daerah Padang Terap. Oleh itu, turut ditemui penggunaan varian [dzubo] di sebahagian kecil kampung di daerah Padang Terap dan Pendang.

\section{e. Varian bunyi [punkumo؟]}

Varian bunyi [puykü ${ }^{\mathrm{o}}$ ] merupakan varian baru yang memiliki identitinya sendiri yang menggabungkan identiti dialek Patani Baling (DPB) dan identiti dialek Melayu Kedah (Asmah, 2008). Kedudukan daerah Baling yang bersempadan dengan Thailand menjadikan daerah ini sebagai kawasan peralihan dialek, yakni antara dialek Kedah dan dialek Patani Baling. Walaupun terdapat beberapa bukit kecil seperti Bukit Pulai dan Bukit Semelak di antara kawasan ini, ia tidak menghalang penyebaran varian [punkum ${ }^{\text {w }}$ ] untuk tersebar dalam kalangan penduduk kampung.

Tambahan pula, pada zaman dahulu bukit dan gunung di kawasan ini menjadi tempat berlindung bagi orang Siam dan Patani yang lari semasa berlakunya perang di negara tersebut. Menurut Asmah (1985), di daerah Baling yang merupakan antara salah satu 
kawasan peralihan dialek di negeri Kedah terdapat golongan penduduk yang menuturkan dialek Kedah, dan ada golongan penduduk yang lain yang menuturkan dialek Patani serta tidak mengenepikan kenyataan bahawa ada penduduk yang mencampuradukkan keduaduanya. Seperti yang dikenal pasti kebanyakan varian ini digunakan secara dominan dalam kalangan penutur di bahagian utara daerah Baling dan sebahagian kampung di daerah Kulim.

\section{f. Varian bunyi [dzubu ${ }^{\mathrm{m}} \mathrm{aS}$ ]}

Memandangkan varian [punkü ${ }^{\mathrm{w}} \mathrm{S}$ ] didapati penyebaran tidak berlaku di keseluruh kampung di daerah Baling dan dilihat dominan penggunaannya di hanya bahagian utara daerah tersebut, ia dilihat berbeza situasi yang berlaku di bahagian selatan daerah Baling ini, iaitu varian [dzubu ${ }^{\mathrm{w}} \mathrm{aS}$ ] pula dilihat lebih banyak penyebaran dan penggunaannya dalam kalangan penutur dialek Melayu di kawasan ini. Menurut Asmah (2008), varian bunyi [dzubu ${ }^{\mathrm{w}} \mathrm{aS}$ ] ini mempunyai persamaan dengan varian [puyku $\left.{ }^{\mathrm{m}} \mathrm{\jmath} \mathrm{S}\right]$ yang merupakan sebutan daripada dialek Petani Baling (DPB). Dapat dikenal pasti kebanyakan varian ini digunakan secara dominan dalam kalangan penutur di bahagian selatan daerah Baling.

\section{Pemetaan varian leksikal 'kerbau'}

Berdasarkan data diperolehi, dapat dikenal pasti bahawa terdapat tujuh (7) varian yang merujuk kepada leksikal 'kerbau' dalam kalangan penutur di negeri Kedah. Antara varian-

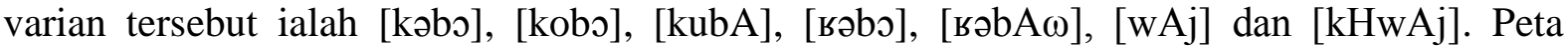
isoglos pada rajah 2 bagi leksikal 'kerbau' memaparkan kawasan penyebaran varian-varian bagi leksikal 'kerbau' berserta dengan taburan bentuk muka bumi yang terdapat dalam negeri Kedah.

\section{a. Varian bunyi [kobo]}

Bagi penggunaan varian [kobo] didapati penyebaran varian ini ditemui di kebanyakan kampung di daerah Bandar Baharu. Varian bunyi [kobo] merupakan ciri asli dialek Melayu Perak. Penggunaan varian bunyi ini begitu dominan di kampung-kampung dalam daerah Bandar Baharu (Asmah, 2008).

Berdasarkan kepada peta isoglos rajah 2, dapat dikesan bahawa kedudukan geografi daerah Bandar Baharu yang berdekatan dan bersempadan dengan negeri Perak telah memudahkan dialek Melayu Perak tersebar masuk dengan meluas ke daerah ini. Oleh sebab itu, penulis menemui banyak penggunaan varian yang dipengaruhi oleh dialek asli Melayu Perak di kampung-kampung di daerah ini. Tambahan lagi, di antara sempadan negeri Perak dan negeri Kedah (daerah Bandar Baharu tersebut), terdapat sebatang sungai yang dikenali sebagai Sungai Kerian dianggap sebagai garisan persempadan antara dua kawasan ini. Hal ini bertepatan dengan dakwaan yang menyatakan bahawa tamadun awal manusia sentiasa bermula dari lembangan sungai.

Malah, fungsi utama Sungai Kerian pada zaman dahulu dilihat sebagai jalan perhubungan dan pengangkutan utama untuk berhubung dengan kawasan-kawasan sekitarnya sama ada berdagang atau sebagainya. Keadaan ini secara tidak langsung juga telah membuka ruang kepada dialek Melayu Perak untuk masuk tersebar di kampung-kampung dalam daerah ini dengan mudah. Walaupun terdapatnya beberapa bukit yang rendah di daerah ini, didapati ia tidak menjadi penghalang kepada penyebaran varian dialek Melayu Perak ke dalam daerah Bandar Baharu. Sebaliknya, dapat dilihat kehadiran gunung di bahagian utara daerah ini pula seperti Gunung Pongsu dan Gunung Keriang secara tidak langsung telah menghalang 
pengaruh dialek Perak yang dominan di daerah ini tersebar ke daerah Kulim. Keadaan ini kerana, untuk sampai ke daerah Kulim, ia perlu melalui daerah Bandar Baharu yang dipenuhi dengan gunung-gunung dan bukit-bukit di bahagian utara daerah Bandar Baharu tersebut. Disebabkan itu, varian asli dialek Melayu Perak bagi leksikal 'kerbau' ini tidak dapat tersebar penggunaannya di kampung-kampung dalam daerah Kulim.

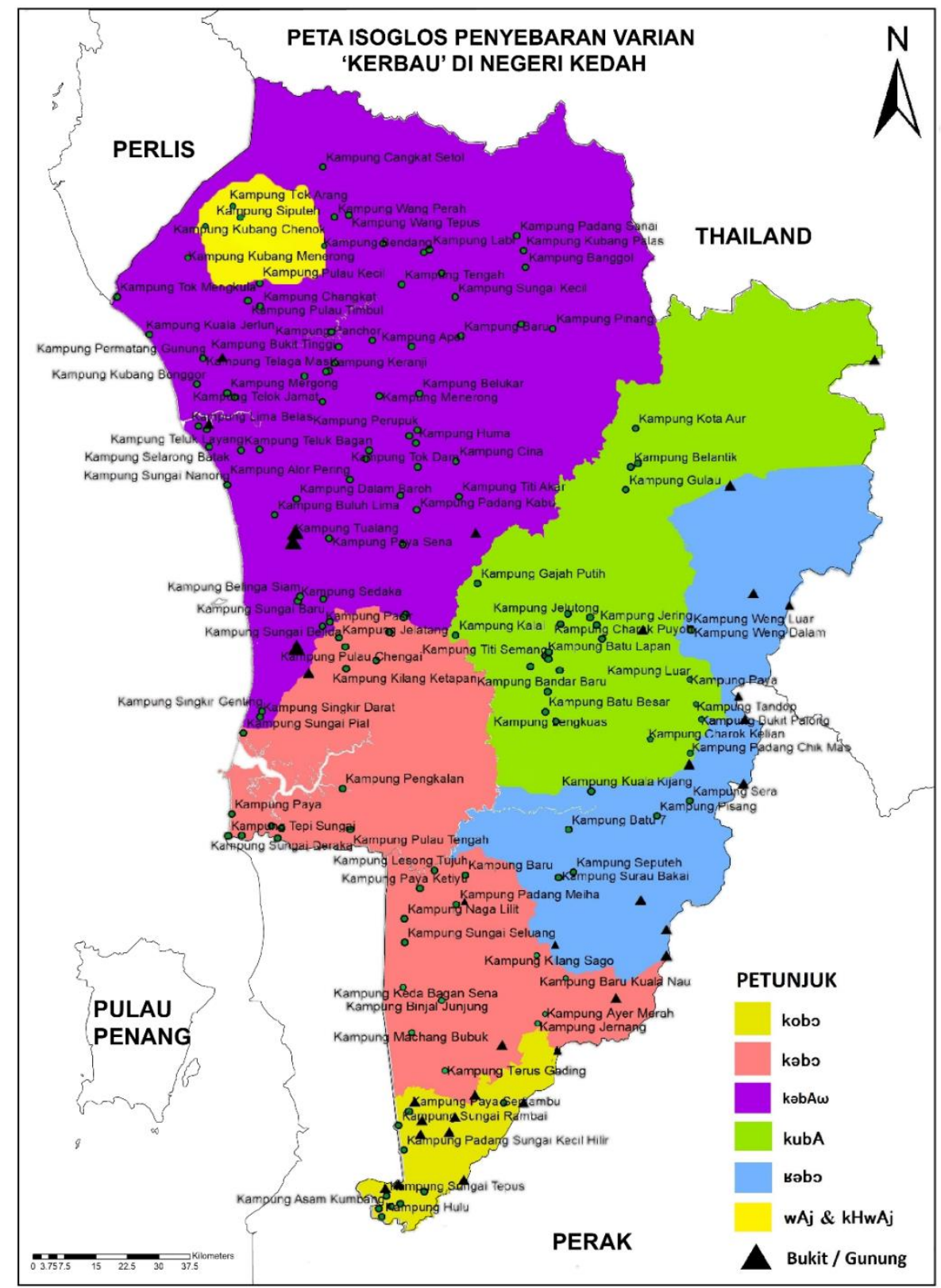

Rajah 2: Varian leksikal 'Kerbau'

b. Varian bunyi [kəbə]

Seterusnya, bagi penggunaan varian [kəbo] pula didapati penyebaran varian ini hanya ditemui di beberapa daerah di bahagian Kedah Persisiran atau Kedah Hilir, iaitu daerah Kulim dan Kuala Muda sahaja. Dari segi keadaan geografi bagi kedua-dua daerah Kuala Muda dan Kulim ini pula, dapat dikenal pasti bahawa kedua-dua kawasan ini berada di kawasan yang rendah, rata, landai dan kurang berbukit menyebabkan pengaruh-pengaruh subdialek Melayu 
Kedah Persisiran mudah tersebar ke kampung-kampung di dalam daerah ini. Di antara dua daerah ini juga terdapat sebatang sungai iaitu Sungai Muda. Ini secara tidak langsung menyatakan bahawa sungai menjadi agen kepada pengaruh subdialek Melayu asli Kedah Persisiran di antara kedua-dua daerah ini. Seperti yang telah dikenal pasti kebanyakan varian ini digunakan secara dominan dalam kalangan penutur di kampug-kampung dalam daerah Kuala Muda dan Kulim.

\section{c. Varian bunyi [kubA]}

Seterusnya, penyebaran dialek Melayu Kelantan di daerah Sik pula dapat dibuktikan dengan kehadiran varian [kubA] di kebanyakan kampung dalam daerah ini. Varian [kubA] turut ditemui penggunaannya di sebahagian kecil kampung di daerah Baling. Varian ini merupakan varian sebutan yang dipengaruhi oleh dialek Kelantan (Ruslan Uthai, 2011).

Apa yang menjadi persoalannya di sini adalah bagaimana varian asli dialek Melayu Kelantan ini boleh sampai pengaruhnya di daerah Sik sedangkan jarak antara negeri Kedah dan negeri Kelantan adalah sangat jauh jika dibandingkan dengan Thailand dan negeri Perak yang bersempadan dengan negeri Kedah ini. Malah, dilihat dari segi kedudukan geografinya pula, dapat dikenal pasti bahawa Thailand dilihat sebagai titik pemisah antara kedua-dua negeri Kelantan dan Kedah ini. Pada hemat penulis, jika difikir secara logiknya dialek atau bahasa Thailand lebih mudah berpengaruh di negeri Kedah jika ingin dibandingkan dengan dialek Kelantan disebabkan jarak pemisahnya yang jauh. Malah di sebelah timur daerah Sik, wujudnya banjaran, gunung-ganang, bukit-bukau dan hutan tebal seperti Banjaran Bintang, Gunung Kemerlong dan Gunung Inas yang dikatakan boleh menjadi penghalang kepada kemasukan pengaruh dialek luar ke kawasan ini.

Menurut Mohd Zamberi (2001), sebenarnya Kelantan dan Patani adalah asalnya dari sebuah negeri yang sama sebelum dipecahkan oleh penjajah Siam-Thai dan Inggeris. Setelah Patani dijajah oleh Siam, ramai ulama-ulama Patani telah berpindah ke Kelantan yang menjadikan Kelantan pula adalah Chermin kepada Patani. Setelah berakhirnya dinasti rajaraja purba, Kelantan dan Patani telah ditadbir oleh golongan ulama dan raja dari keturunan Sayyid Ahmad Jalaluddin menerusi anaknya Sayyid Hussin Jamadil Kubro. Malah, Patani dan Kelantan adalah sebuah entiti yang sama semenjak zaman Langkasuka lagi. Setelah lenyapnya Langkasuka, muncul pula nama Chermin atau Waruwari bagi kedua buah negeri yang sempadan negerinya dicipta oleh Inggeris dan Siam-Thai pada abad ke-20 (Mohamed Sukeri, Rohana, Mohamad Mustafa, Abdul Rahman, Mohd. Fo'ad \& Shafee, 2002). Jadi, tidak hairanlah bahawa terdapat pengaruh dialek Kelantan yang wujud di Sik.

\section{d. Varian bunyi [вәbо]}

Bagi penggunaan varian [вәbə] pula didapati penyebaran varian ini hanya ditemui di beberapa kampung di dalam daerah Baling sahaja. Varian ini merupakan varian yang menggabungkan identiti dialek Melayu Patani dan dialek Melayu asli Perak, dan ia dikenali sebagai dialek Patani Baling. Dari segi sudut geografinya pula, dapat dikenal pasti bahawa terdapat beberapa batang sungai di daerah Baling yang pada suatu ketika dahulunya pernah menjadi laluan perdagangan dari pedagang dalam dan luar. Keadaan sungai-sungai tersebut yang sangat dalam menyebabkan ia dijadikan sebagai laluan pedagang luar ke negeri Kedah, khususnya di Baling.

Tambahan lagi, kedudukan daerah Baling yang berhampiran dengan Selatan Thailand (Yala) menjadikan daerah ini sebagai kawasan peralihan dialek, yakni antara dialek Kedah dan dialek Patani. Walaupun terdapat beberapa bukit kecil seperti Bukit Pulai dan Bukit Semelak di antara kawasan ini, ia tidak menghalang penyebaran varian [вәbо] untuk tersebar 
dalam kalangan penduduk kampung di Baling. Pada zaman dahulu bukit dan gunung di kawasan ini dikenal pasti menjadi tempat berlindung bagi orang Siam dan Patani yang lari semasa berlakunya perang di negara tersebut. Tambahan lagi, menurut Asmah (1985), di daerah Baling yang merupakan antara salah satu kawasan peralihan dialek di negeri Kedah terdapat golongan penduduk yang menuturkan dialek Kedah, dan ada golongan penduduk yang lain yang menuturkan dialek Patani serta tidak mengenepikan kenyataan bahawa ada penduduk yang mencampuradukkan kedua-duanya.

\section{e. Varian bunyi [wAj] dan [kHwAj]}

Berpandukan kepada peta isoglos di rajah 2, dapat diperhatikan di bahagian Kubang Pasu terdapat terdapat beberapa perkampungan yang menuturkan varian [wAj] dan [kHwAj] iaitu varian yang dipengaruhi sebutannya oleh bahasa Thai. Walaupun kedudukan Kubang Pasu yang dilihat jauh dengan Thailand, ia tetap membolehkan pengaruh varian [wAj] dan [kHwAj] masuk tersebar di beberapa kampung di bahagian Kubang Pasu. Seperti yang dikenal pasti kebanyakan varian ini digunakan secara dominan dalam kalangan penutur di kampug-kampung dalam daerah Kubang Pasu.

Menurut Ismail Hamid (1988), ini terjadi kerana pada sebelum dan sesudah Perang Dunia Kedua, terdapat penghijrahan secara besar-besaran dari Thailand Selatan ke daerah Kubang Pasu. Di sebelah barat mukim Jitra (daerah Kubang Pasu), terdapat perkampungan orang-orang Melayu yang asalnya dari Thai Selatan, yang bahasa pertama mereka (yakni generasi pertama penghijrahan tersebut) adalah bahasa Thai Selatan. Kampung itu dikenali sebagai Kampung Tok Arang dan Kampung Menerong. Jadi, tidak hairanlah terdapat perkampungan orang Siam yang masih menuturkan bahasa Siam dalam kehidupan seharian mereka di kampung daerah Kubang Pasu ini atas dasar atau faktor migrasi.

\section{Kesimpulan}

Berdasarkan dapatan yang diperolehi, dapat disimpulkan bahawa taburan pelbagai varian dialek Melayu di negeri Kedah dapat dikenal pasti berdasarkan perbezaan fonologi yang mewakili sesuatu dialek. Begitu juga dengan ruang geografi seperti sempadan, sungai, gunung, bukit, hutan dan sebagainya turut menyumbang kepada penyebaran pelbagai varian ini dalam kalangan penutur dialek Melayu di Kedah.

Persempadanan kawasan di antara daerah mahupun negeri didapati telah memberi ruang kepada penyebaran varian dialek Melayu di negeri Kedah. Hal ini dibuktikan oleh penggunaan varian di daerah Bandar Baharu. Kita sedia maklum bahawa kedudukan daerah Bandar Baharu yang bersempadan negeri Perak. Oleh sebab itu dapat dilihat terdapat pengaruh dialek Melayu Perak yang ditemui tersebar di banyak kampung di daerah Bandar Baharu. Begitu juga situasinya di Sik dan Baling. Memandangkan kedua-dua daerah adalah bersempadan dan berhampiran dengan Selatan Thailand, jadi dapat dilihat banyak pengaruh dialek Patani dan Siam yang tersebar masuk ke kedua-dua daerah ini. Sebagai contoh, dapat dilihat pengaruh dialek Melayu Perak melalui varian 'kerbau' iaitu banyak dijumpai di kawasan daerah Bandar Baharu. Begitu juga dengan dialek Melayu Patani melalui varian, iaitu juga banyak ditemui di kampung-kampung di daerah Sik dan Baling.

Selain itu juga, sungai juga didapati berperanan besar dalam memberi ruang kepada penyebaran dialek Melayu di negeri Kedah. Sebagai contoh, di antara daerah Sik dan Padang Terap dipisahkan oleh Sungai Beris. Dengan adanya Sungai Beris, ia memudahkan perhubungan berlaku antara kawasan ini. Dengan wujudnya Sungai Beris antara daerah Sik dan Padang Terap ini juga, ia pastinya wujud aktiviti nelayan yang melibatkan penduduk bagi 
kedua-dua daerah ini. Sungai Beris ini juga dilihat sebagai jalan penghubung di antara dua kawasan tersebut dan ini secara tidak langsung telah membuka ruang kepada penyebaran dialek Patani Sik ke dalam daerah Padang Terap. Oleh itu, turut ditemui penggunaan varian [e] yang merupakan varian dialek Patani Sik di sebahagian kecil kampung di daerah Padang Terap dan Pendang. Begitu juga dengan kehadiran gunung, bukit dan hutan tebal di kebanyakan kawasan dalam negeri Kedah.

Hasil dapatan analisis jelas menunjukkan bahawa berlakunya kerencaman dalam dialek Melayu di negeri Kedah bagi leksikal 'punggung' dan 'kerbau'. Kerencaman ini berlaku kerana faktor kemasukan pengaruh dialek daripada dialek-dialek setempat seperti dialek Melayu dan dialek asli Melayu Kedah sendiri serta dialek-dialek luar seperti dialek Siam, dialek Petani Sik, dialek Petani Baling dan bahasa Thailand itu sendiri ke dalam negeri Kedah yang menyebabkan kewujudan pelbagai varian bagi leksikal tersebut. Kerencaman varian-varian ini juga dilihat terjadi juga adalah disebabkan oleh faktor ruang geografi di negeri Kedah itu sendiri. Keadaan negeri Kedah yang berbukit-bukau, bergunung-ganang dan sungai telah mempengaruhi penyebaran variasi leksikal dialek Melayu di negeri ini. Walau bagaimanapun, berdasarkan analisis yang telah dilakukan membuktikan bahawa bentuk muka bumi di negeri Kedah dilihat ada yang membuka dan menutup ruang kepada kerencaman dan penyebaran variasi leksikal yang dikaji.

\section{Penghargaan}

Kajian ini dibiayai oleh geran penyelidikan fundamental oleh Kementerian Pengajian Tinggi (FRGS/1/2015/SSI01/UKM/02/3).

\section{Rujukan}

Abdul Hamid Mahmood. (1993). Guru dan bahasa Melayu. Kuala Lumpur, Dewan Bahasa dan Pustaka.

Ajid Che Kob. (1984). Dialek geografi Pasir Mas. Bangi, Penerbit Universiti Kebangsaan Malaysia.

Asmah Haji Omar. (1985). Susur galur bahasa Melayu. Kuala Lumpur, Dewan Bahasa dan Pustaka.

Asmah Haji Omar. (2008). Ensiklopedia bahasa Melayu. Kuala Lumpur, Dewan Bahasa dan Pustaka.

Collins, J. T. (1986). Antologi kajian dialek Melayu. Kuala Lumpur, Dewan Bahasa dan Pustaka.

Collins, J. T. (1987). Dialek Melayu Sarawak. Bangi, Penerbit Universiti Kebangsaan Malaysia.

Collins, J. T. (1983). Dialek Ulu Terengganu. Bangi, Penerbit Universiti Kebangsaan Malaysia.

Collins, J. T. (1996). Khazanah dialek Melayu. Bangi, Penerbit Universiti Kebangsaan Malaysia.

Fazal Mohamed Mohamed Sultan \& Noriati Muhamad (2017). Kata soal dalam Dialek Perlis. Jurnal Akademika, 87(1), 177-187.

Ismail Dahaman. (1997). Glosari dialek Kedah. Kuala Lumpur, Dewan Bahasa dan Pustaka. Ismail Hamid. (1988). Peradaban Melayu dan Islam. Kuala Lumpur, Penerbit Fajar.

Mario, A. P. \& Gaynor, F. (1960). A dictionary of linguistics. New Jersey, Adam \& co. 
Meillet, A. (1967). Comparative method in historical linguistics. Evanston, Adler's Foreign Books.

Maizatul Hafizah. (2016). Variasi leksikal dialek di Langkawi: analisis geolinguistik. Tesis Sarjana. Bangi: Universiti Kebangsaan Malaysia.

Mohamed Sukeri Khalid, Rohana Yusof, Mohamad Mustafa Ishak, Abdul Rahman Aziz, Mohd. Fo'ad Sakdan \& Shafee Saad. (2002). Kedah 100 tahun: 1900-2000 (isu-isu politik \& sosioekonomi). Kedah, Penerbit Universiti Utara Malaysia.

Mohd Tarmizi Hasrah, Rahim Aman \& Shahidi A.H. (2012). Menelusuri alur lembangan Hulu Pahang: menjejaki sistem vokal dialek Hulu Pahang. Dlm. Rahim Aman (Pnyt.), Bahasa Melayu Bahasa Universal (hlm.79-96). Bangi, Penerbit Universiti Kebangsaan Malaysia.

Nor Hashimah Jalaluddin. (2015). Penyebaran dialek Patani di Perak: analisis geolinguistik. Melayu: Jurnal Antarabangsa Dunia Melayu, 8(2), 310-330.

Nor Hashimah Jalaluddin, Zaharani Ahmad, Harishon Radzi, \& Norlisafina Sanit. (2016). Variasi kata ganti nama dialek di pesisir Perak: Analisis geographical information system (GIS). GEMA Online Journal of Language Studies, 16(1), 109-123.

Onishi, T. (2010). Analyzing dialectological distributions of Japanese. Dialectologia Journal, $1,123-135$.

Raja Mukhtaruddin Raja Mohd. Dain. (1986). Dialek Perak. Ipoh, Yayasan Perak.

Rohani Mohd Yusof. 1986. Dialek geografi Kuala Kangsar: satu kajian perbandingan fonologi. Disertasi Sarjana. Kuala Lumpur, Universiti Malaya.

Rohani Mohd Yusof. (2003). Kuala Kangsar sebagai zon transisi dialek. Jurnal Bahasa, $3(4), 588-606$.

Ruslan Uthai. (2011). Keistimewaan dialek Melayu Patani. Bangi, Penerbit Universiti Kebangsaan Malaysia.

Sakinah Nik Muhammad Naziman \& Fazal Mohamed Mohamed Sultan. (2016). Bentuk dan kedudukan kata tanya dialek Perak Utara: Satu huraian deskriptif. Jurnal Bahasa, 16(2),253-274.

Teeraroanarat, S \& Tigsabadh, K. (2011). A GIS-based approach for dialect boundary studies. Jurnal Dialectologia of Universitat de Barcelona, 6, 55-75. 